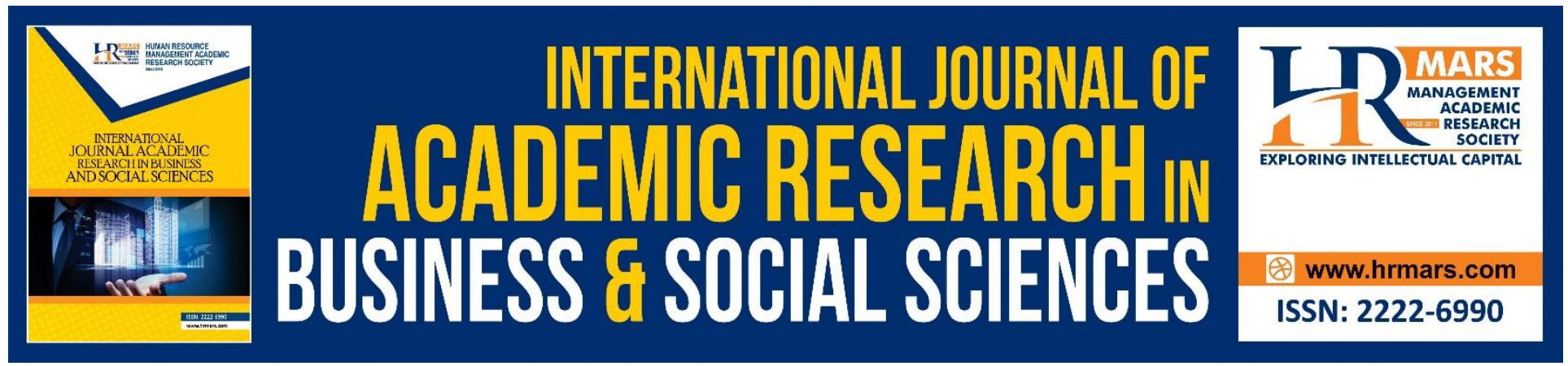

\title{
Teachers' Understanding and the Level of Implementation of Authentic Elements in the Teaching of Malay Language Writing and Their Relationships with School Type, Teachers' Experience, and Specialization
}

Zulkifli Osman, Anida Sarudin, Abu Hassan Abdul, and Razali Ayob

To Link this Article: http://dx.doi.org/10.6007/IJARBSS/v9-i1/5787

DOI: $10.6007 /$ IJARBSS/v9-i1/5787

Received: 1 Jan 2018, Revised: 27 Jan 2019, Accepted: 11 Feb 2019

Published Online: 23 Feb 2019

In-Text Citation: (Osman, Sarudin, Abdul, \& Ayob, 2019)

To Cite this Article: Osman, Z., Sarudin, A., Abdul, A. H., \& Ayob, R. (2019). Teachers' Understanding and the Level of Implementation of Authentic Elements in the Teaching of Malay Language Writing and Their Relationships with School Type, Teachers' Experience, and Specialization. International Journal Academic Research Business and Social Sciences, 9(1), 1245-1256.

Copyright: (c) 2019 The Author(s)

Published by Human Resource Management Academic Research Society (www.hrmars.com)

This article is published under the Creative Commons Attribution (CC BY 4.0) license. Anyone may reproduce, distribute, translate and create derivative works of this article (for both commercial and non-commercial purposes), subject to full attribution to the original publication and authors. The full terms of this license may be seen

at: http://creativecommons.org/licences/by/4.0/legalcode

$$
\text { Vol. 9, No. 1, 2019, Pg. } 1245 \text { - } 1256
$$




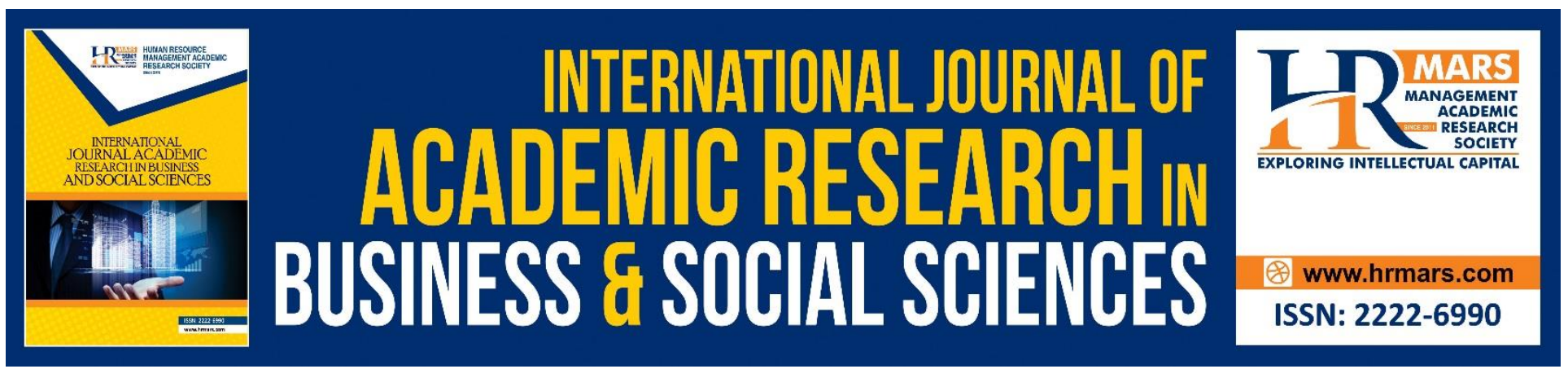

\title{
Teachers' Understanding and the Level of Implementation of Authentic Elements in the Teaching of Malay Language Writing and Their Relationships with School Type, Teachers' Experience, and Specialization
}

\author{
Zulkifli Osman, Anida Sarudin, Abu Hassan Abdul, and Razali Ayob \\ Faculty of Languages and Communication, Sultan Idris Education University, Malaysia
}

\begin{abstract}
The aim of this study is to examine teachers' understanding and the level of implementation of authentic elements in their teaching of Malay language writing by focusing on the relations of the above factors (dependent variables) with three independent variables, namely school category, teachers' experience and specialization. The research design of this study was based on a quantitative approach using a survey method. In this survey, a questionnaire was used to examine the level of implementation of authentic elements in the teaching and learning process of Malay essay writing involving Form-Two students (aged 14 years). The teacher questionnaire consisted of three parts to elicit information pertaining to teachers' background, the level of the implementation of authentic elements in their teaching practice, and their comments and suggestions. The participants of this study were 193 teachers who were selected from 59 low-performance schools throughout Malaysia. Descriptive and correlational analyses were performed using SPSS. The analyses revealed that the overall implementation of authentic elements in the teaching process was at the moderate level. Furthermore, the relations of all variables, except teachers' specialization, were found to be not significant. Even though the strength of the relationship between teachers' specialization and the implementation of authentic elements in their teaching practice was found to be small, such a finding may raise some concerns among the stakeholders, notably school administrators. Clearly, teachers who are less specialized in teaching Malay language writing may need more guidance to help them use more authentic elements in their teaching practice. As such, they may require sufficient resources and support to help improve their teaching practice, the impact of which can help improve students' learning performance.
\end{abstract}

Keywords: Authentic Elements, Low-Performance Schools, Malay Essay Writing, Teachers' Experience, Teachers' Specialization, School Category. 


\section{Introduction}

This study focuses on the infusion of authentic elements in the teaching of Malay language essay writing at low-performance schools. In this study, the principles of and authentic elements are based on Herrington and Herrington's (2007), authentic learning model. In essence, authentic learning is a learning process that engenders a real world learning environment. Such a learning process entails the use of teachers' senses to create meaningful learning. In fact, such an approach is in line with the requirements of PPM 2015-25, whcih emphasizes giving priority to authentic assessment. According to Zemelman, Daniels, and Hyde (2005), Herrington and Herrington (2007); Muijs and Renolds (2011), authentic learning can attract teachers' attention, which is vital to ensuring students will engage actively in learning. In the context of language learning, the infusion of authentic elements can help improve students' learning performance (Ghaderpanahi, 2012; Mousavi, 2012; Homaci, 2014; Esfahandiari, 2014; Klipfel, 2014; Guo, 2012; Zoghi, Zardah, and Kazemi, 2014; Ghanbari, 2015; Grim, 2010; Gilmore, 2007; Hussain Raja, 2015)

In language learning, such infused elements will be able to improve teachers' achievements and creativity, as demonstrated in a study by Hazrati, Rosseni, Aidah, Helmi and Analisa (2013). They argue that such elements are able to create an engaging learning environment that empowers students to engage in meaningful learning. Through the principle of 'learning by doing' and contextualized learning, learning process engaged by students will be more meaningful, thus strengthening their understanding and knowledge of a concept over time. In particular, in a study by Osman (2016), it was found that authentic learning was able to improve quality of teachers' essays. Despite the recognition of the educational benefits of authentic elements, authentic learning has not thus far been extensively applied in the classroom, most notably in language learning. Such contention is not unfounded as studies by Osman (2013a and 2013b) and Yusoff et al. (2010) observed that teachers were still practicing the conventional approach in the teaching of Malay language. In particular, they observed that teachers relied heavily on textbook as the main learning material. Against such a backdrop, this study was carried out with the main aim to examine the implementation of authentic elements in the teaching and learning process of Malay language and its relationship with several teachers' demographic, namely their experience, specialization, and location. In particular, the authentic elements that served as the focus of this study were based on Herrington and Herrington's (2007) nine approaches as follows:

a) Provide authentic contexts to ensure knowledge can be applied in the actual contexts.

b) Create authentic learning activities that are relevant to the real world and complex assignments that need to be completed based on a prescribed duration.

c) Exposure students to the problem-solving process or to assignments that are realistic with the actual contexts.

d) Encourage students to explore multiple perspectives and diverse roles.

e) Collaborate with one another to help develop knowledge.

f) Reflect on the problems and their solutions.

g) Articulate discussions among students.

h) Provide scaffolding for students during the learning process. 
INTERNATIONAL JOURNAL OF ACADEMIC RESEARCH IN BUSINESS AND SOCIAL SCIENCES Vol. 9, No. 1, Jan, 2019, E-ISSN: 2222-6990 (C) 2019 HRMARS

i) Carry out the authentic assessment.

Table 1 summarizes the way in which these elements were implemented in the teaching of Malay language essay writing.

Table 1. The Nine Elements in the Teaching and Learning of Malay Language Composition

\begin{tabular}{|c|c|c|c|c|}
\hline No. & Element & Description & Issue & $\begin{array}{l}\text { Language } \\
\text { skill/Learning } \\
\text { material }\end{array}$ \\
\hline 1 & $\begin{array}{l}\text { Authentic } \\
\text { context. }\end{array}$ & $\begin{array}{l}\text { A physical or visual } \\
\text { environment that } \\
\text { reflects the knowledge } \\
\text { to be used in the actual } \\
\text { situation. }\end{array}$ & $\begin{array}{l}\text { - } \quad \text { Complex scenario. } \\
\text { - } \text { Real-world problem } \\
\text { and teachers' actual } \\
\text { environment. }\end{array}$ & $\begin{array}{l}\text { Reading online news } \\
\text { or any similar } \\
\text { materials to create an } \\
\text { authentic learning } \\
\text { context. }\end{array}$ \\
\hline 2 & $\begin{array}{l}\text { Authentic } \\
\text { assignment. }\end{array}$ & $\begin{array}{l}\text { Assignments and } \\
\text { activities that are } \\
\text { relevant to the real } \\
\text { world. }\end{array}$ & - Floods at your place. & $\begin{array}{l}\text { Writing an appeal } \\
\text { letter to seek } \\
\text { assistance. }\end{array}$ \\
\hline 3 & $\begin{array}{l}\text { Expert } \\
\text { achievement. }\end{array}$ & $\begin{array}{l}\text { Refer to the } \\
\text { expert's view to } \\
\text { help solve a } \\
\text { problem. } \\
\text { Refer to the } \\
\text { multiple } \\
\text { perspectives in } \\
\text { dealing with an } \\
\text { important issue. }\end{array}$ & - Price hikes of goods. & $\begin{array}{l}\text { - A news cutting or } \\
\text { an excerpt of an } \\
\text { interview } \\
\text { involving an } \\
\text { expert with } \\
\text { regard to issues of } \\
\text { price hikes of } \\
\text { good. } \\
\text { - Talk by an expert. } \\
\text { - The historical } \\
\text { account of a } \\
\text { personality or an } \\
\text { expert. }\end{array}$ \\
\hline 4 & $\begin{array}{l}\text { Multiple } \\
\text { perspectives } \\
\text { and } \\
\text { differential } \\
\text { views }\end{array}$ & $\begin{array}{l}\text { Different perspectives } \\
\text { originate from different } \\
\text { views. As such, use a } \\
\text { number of channels, } \\
\text { such as media, to learn } \\
\text { such diverse } \\
\text { perspectives. }\end{array}$ & $\begin{array}{l}\text { - Is it wise for our } \\
\text { nation to send an } \\
\text { astronaut to the } \\
\text { moon? }\end{array}$ & $\begin{array}{l}\text { - } \text { Database. } \\
\text { - } \text { Digital library. } \\
\text { - Influential } \\
\text { websites. }\end{array}$ \\
\hline 5 & Collaboration & $\begin{array}{l}\text { Activities that help the } \\
\text { public, such as those }\end{array}$ & - Homeless people. & $\begin{array}{l}\text { Writing an article } \\
\text { or publishing a }\end{array}$ \\
\hline
\end{tabular}


INTERNATIONAL JOURNAL OF ACADEMIC RESEARCH IN BUSINESS AND SOCIAL SCIENCES Vol. 9, No. 1, Jan, 2019, E-ISSN: 2222-6990 @ 2019 HRMARS

\begin{tabular}{|c|c|c|c|c|}
\hline & & $\begin{array}{l}\text { carried out by a charity } \\
\text { organization. }\end{array}$ & & $\begin{array}{l}\text { bulletin to } \\
\text { highlight such an } \\
\text { issue to the } \\
\text { general public. }\end{array}$ \\
\hline 6 & Reflection & $\begin{array}{l}\text { Opportunity for } \\
\text { students to think, } \\
\text { reflect, and discuss } \\
\text { their choices. }\end{array}$ & $\begin{array}{l}\text { - Opportunity to make } \\
\text { choices. } \\
\text { - Two-way discussion } \\
\text { process. } \\
\text { - Opportunity to } \\
\text { reflect on online } \\
\text { journals, books, and } \\
\text { materials that have } \\
\text { been read or listen } \\
\text { to. }\end{array}$ & $\begin{array}{l}\text { Reading articles in } \\
\text { a journal or a blog } \\
\text { and making } \\
\text { reflections. }\end{array}$ \\
\hline 7 & Articulation & $\begin{array}{l}\text { Opportunity for } \\
\text { students to write and } \\
\text { speak out about their } \\
\text { understanding of a } \\
\text { subject matter or an } \\
\text { issue. }\end{array}$ & $\begin{array}{l}\text { - General presentation } \\
\text { in which students } \\
\text { defend their ideas } \\
\text { - Comment on an issue } \\
\text { through online } \\
\text { media, such as } \\
\text { Twitter and } \\
\text { Facebook. }\end{array}$ & $\begin{array}{l}\text { Responding by } \\
\text { posting } \\
\text { comments to } \\
\text { YouTube and } \\
\text { other alternative } \\
\text { media }\end{array}$ \\
\hline 8 & $\begin{array}{l}\text { Training and } \\
\text { Scaffolding }\end{array}$ & $\begin{array}{l}\text { - Knowledge transfer } \\
\text { is not the only } \\
\text { concern. } \\
\text { - Teachers will focus } \\
\text { not only on } \\
\text { teaching but also } \\
\text { on helping students } \\
\text { in constructing } \\
\text { knowledge and } \\
\text { correcting } \\
\text { mistakes. }\end{array}$ & $\begin{array}{l}\text { - Students are given } \\
\text { the opportunity to } \\
\text { write an essay about } \\
\text { themselves. } \\
\text { - The teacher helps the } \\
\text { students to improve } \\
\text { their writing. } \\
\text { - The teacher supports } \\
\text { the students by } \\
\text { giving online articles, } \\
\text { printed materials, } \\
\text { and others, to them, } \\
\text { with which they will } \\
\text { use as guidelines to } \\
\text { help correct their } \\
\text { mistakes. }\end{array}$ & $\begin{array}{l}\text { - Essay } \\
\text { composition. }\end{array}$ \\
\hline 9 & $\begin{array}{l}\text { Authentic } \\
\text { assessment }\end{array}$ & $\begin{array}{l}\text { Assessments have to } \\
\text { be aligned with the } \\
\text { teachers' assignments. }\end{array}$ & $\begin{array}{l}\text { - Assessments must } \\
\text { relate with the } \\
\text { assessments given to } \\
\text { the students. }\end{array}$ & $\begin{array}{l}\text { - } \text { Reports. } \\
\text { - Journals }\end{array}$ \\
\hline
\end{tabular}


INTERNATIONAL JOURNAL OF ACADEMIC RESEARCH IN BUSINESS AND SOCIAL SCIENCES

Vol. 9, No. 1, Jan, 2019, E-ISSN: 2222-6990 ㄷ 2019 HRMARS

Two research questions were formulated to guide this research as follows:

a) What are the levels of the infusion of authentic elements in the teaching of Malay language essay writing in the classroom and teachers' understanding of Malay language essay writing?

b) What are the relations of teachers' experience, specialization, and school category with such levels?

Accordingly, to answers the above research questions, six research hypotheses were formulated in this research as follows:

H1: The relationship of school type with the level of teachers' understanding of authentic elements is not significant.

$\mathrm{H}$ 2: The relationship of school category with the level of the implementation of authentic elements in their teaching practice of Malay essay writing is not significant.

H3: The relationship of teachers' experience with the level of teachers' understanding of authentic elements is not significant.

H4: The relationship of teachers' experience with the level of the implementation of authentic elements in their teaching practice of Malay essay writing is not significant.

H5: The relationship of teachers' specialization with the level of teachers' understanding of authentic elements is not significant.

H6: The relationship of teachers' specialization with the level of the implementation of authentic elements in their teaching practice of Malay essay writing is not significant.

\section{Research Design}

This research design of this study was based on a quantitative approach using a survey method. The survey was carried out with the aim to assess the level of understanding of Malay language writing of a group of teachers and the level of implementation of authentic elements in learning at a lowperformance school. Specifically, this study was conducted to examine the relations of such levels with teachers' experience, specialization, and school category.

\section{Participants}

The participants of this study were 193 teachers who were selected from 59 low-performance schools throughout Malaysia. Such schools were those that had attained a performance band of 5.5, which is low based on the performance rating of Malaysian public schools. Out of the selected schools, 27 schools are located in urban areas, while the remaining 32 schools are located in non-urban areas.

\section{Research Instrument}

The research instrument of the study was based on a questionnaire that was used to examine the level of implementation of authentic elements in the teaching and learning process of Malay essay writing involving Form-Two students (aged 14 years) in several selected low-performance schools. The questionnaire consisted of three parts to elicit information pertaining to teachers' background, 
INTERNATIONAL JOURNAL OF ACADEMIC RESEARCH IN BUSINESS AND SOCIAL SCIENCES

Vol. 9, No. 1, Jan, 2019, E-ISSN: 2222-6990 @ 2019 HRMARS

the level of the implementation of authentic elements in the teaching of Malay language essay writing, and their comments and suggestions. To help interpret the mean scores of the responses of the questionnaire, the researchers used the balanced judgment proposed by Shaari, Yusof, Khan, Mei, and Teong (2008). Table 2 summarizes the interpretation of such scores.

Table 2. Interpretation of the Levels of Implementation of Authentic Elements (As Perceived by Teachers)

\begin{tabular}{lll}
$\begin{array}{l}\text { Calculation of } \\
\text { interval }\end{array}$ & Mean score & $\begin{array}{l}\text { Interpretation of the levels } \\
\text { of implementation of } \\
\text { authentic elements }\end{array}$ \\
\hline $5-1$ \\
\hline 4
\end{tabular}$\quad$\begin{tabular}{ll}
$1.00-2.00$ & Low \\
$2.01-3.00$ & Moderately Low \\
$3.01-4.00$ & Moderately High \\
$4.01-5.00$ & High \\
\hline
\end{tabular}

A series of Pearson's correlation tests were performed to examine the relations of the level of such implementation with teachers' experience, specialization, and teaching location. According to Ahmad Hashim (2014), interpreting such a table entails researchers to examine the level of significance of the correlation coefficients $(r)$, which can either be positive or negative.

\section{Results}

Descriptive analysis of the survey data was carried out using SPSS, the results of which are summarized in Table 3. Clearly, the level of the implementaion of authentic elements in the teaching of Malay essay writing in the classrooms of selected low-performance schools was moderately high, as evidenced by a mean score of 3.95. More impressive, with a mean score of 4.21, the level of understanding of teachers with regard to authentic elements was high. In addition, their opinions of such implementation was moderately high, attested by a mean score of 3.69. Such findings clearly showed that the implemention of athentic elements in the teaching process was only moderate, despite the higher level of teacher's understanding of such elements. 
INTERNATIONAL JOURNAL OF ACADEMIC RESEARCH IN BUSINESS AND SOCIAL SCIENCES

Vol. 9, No. 1, Jan, 2019, E-ISSN: 2222-6990 @ 2019 HRMARS

Table 3. Level of the Implementation of Authentic Elements in the Teaching and Learning Process of Malay Essay Writing

\begin{tabular}{lccc}
\hline Measure & SD & $\begin{array}{l}\text { Mean } \\
\text { score }\end{array}$ & Interpretation \\
\hline $\begin{array}{l}\text { The teachers' understanding of authentic } \\
\text { elements in the teaching process. }\end{array}$ & .61 & 4.21 & High \\
\hline $\begin{array}{l}\text { The level of the implementation of authentic } \\
\text { elements in the teaching practice. }\end{array}$ & .70 & 3.69 & $\begin{array}{c}\text { Moderately } \\
\text { High }\end{array}$ \\
\hline $\begin{array}{l}\text { Overall implementation of authentic elements in } \\
\text { the teaching process }\end{array}$ & & 3.95 & $\begin{array}{c}\text { Moderately } \\
\text { High }\end{array}$ \\
\hline
\end{tabular}

A series of Pearson's correlation analyses was carried out to determine whether the relations of teachers' experience, specialization, and teaching location with the level of implementation of authentic elements in teaching are significant or not. Table 4 shows the correlation matrix of the relationship of school category with the level of implementation and teachers' understanding of authentic elements in the teaching process. As shown, the relationship between school category and teachers' understanding was very weak, negative, and not significant, $r(193)=-.10, p>.05$. This finding showed that the levels of understanding of teachers with regard to the implementation of authentic elements in the teaching process at the urban and non-urban schools were similar. Likewise, the relationship between school category and the level of the implementation of authentic elements in the teaching practice was very weak, negative, and not significant, $r(193)=-.06, p>.05$. This finding indicated that teachers of both urban and non-urban schools had the same levels of implementation of authentic elements in their teaching process.

Table 4. The Correlation Matrix of the Relations of the School Category with the Levels of Implementation and Teachers' Understanding of Authentic Elements in Learning

\begin{tabular}{llcc}
\hline & & \multicolumn{1}{c}{$\begin{array}{c}\text { Teachers' } \\
\text { understanding }\end{array}$} & $\begin{array}{c}\text { Level of } \\
\text { implementation }\end{array}$ \\
\hline \multirow{3}{*}{$\begin{array}{l}\text { School } \\
\text { category }\end{array}$} & $\begin{array}{l}\text { Pearson } \\
\text { Correlation }\end{array}$ & -.10 & -.06 \\
\cline { 2 - 4 } & Sig.(2-tailed) & .19 & .43 \\
\cline { 2 - 4 } & $\mathrm{N}$ & 193 & 193 \\
\hline
\end{tabular}

* Correlation is significant at the .05 level (2-tailed).

Table 5 shows the correlation matrix of teachers' experience with the level of implementation and teachers' understanding of authentic elements in the teaching process. As shown, the relationship between teachers' experience and teachers' understanding was very weak and not significant, $r(193)$ $=.07, p>.05$. This finding showed that the levels of understanding of teachers were the same irrespective of the number of years they have been working. Similarly, the relationship between 
INTERNATIONAL JOURNAL OF ACADEMIC RESEARCH IN BUSINESS AND SOCIAL SCIENCES Vol. 9, No. 1, Jan, 2019, E-ISSN: 2222-6990 ㄷ 2019 HRMARS

teachers' experience and the level of implementation was extremely weak and not significant, $r(193)$ $=.007$. This finding indicated that the levels of implementation of authentic elements in the teaching and learning process were the same regardless of their working experiences.

Table 5: The correlation matrix of the relations of the teachers' experience with the levels of implementation and teachers' understanding of authentic elements in learning

\begin{tabular}{llcc}
\hline & \multicolumn{1}{c}{$\begin{array}{c}\text { Teachers' } \\
\text { understanding }\end{array}$} & $\begin{array}{c}\text { Level of } \\
\text { implementation }\end{array}$ \\
\hline \multirow{2}{*}{$\begin{array}{l}\text { Teachers' } \\
\text { experience }\end{array}$} & $\begin{array}{l}\text { Pearson } \\
\text { Correlation }\end{array}$ & .07 & .007 \\
\cline { 2 - 4 } & Sig. (2-tailed) & .36 & .92 \\
\cline { 2 - 4 } & $\mathrm{N}$ & 193 & 193 \\
\hline
\end{tabular}

* Correlation is significant at the .05 level (2-tailed).

Table 6 shows the correlation matrix of the relations of teachers' specialization with the level of implementation and teachers' understanding. As shown, the relationship between teachers' specialization and teachers' understanding was very weak, negative, and not significant, $r(193)=-$ $.10, p>.05$. This finding showed that the levels of understanding of teachers were the same irrespective of their specialization. Interestingly, the relationship between teachers' specialization and level of implementation was marginally significant, but weak, $r(193)=.14, p=.05$. This finding indicated that the levels of implementation of authentic elements in the teaching and learning process were marginally different. However, given that the magnitude of such relationship was weak, such a difference did not have any practical significant.

Table 6: The correlation matrix of teachers' specialization with the levels of implementation and teachers' understanding of authentic elements in learning

\begin{tabular}{|c|c|c|c|c|}
\hline & & $\begin{array}{c}\text { Teachers' } \\
\text { understanding }\end{array}$ & $\begin{array}{c}\text { Level of } \\
\text { implementation }\end{array}$ & \\
\hline \multirow[t]{3}{*}{$\begin{array}{l}\text { Teachers' } \\
\text { specialization }\end{array}$} & $\begin{array}{l}\text { Pearson } \\
\text { Correlation }\end{array}$ & -.10 & .14 & \multirow{3}{*}{$\begin{array}{l}* \text { Correlation is } \\
\text { significant at the } \\
0.05 \text { level } \\
\text { tailed). }\end{array}$} \\
\hline & Sig. (2-tailed) & .16 & $.05^{*}$ & \\
\hline & $\mathrm{N}$ & 193 & 193 & \\
\hline
\end{tabular}

\section{Discussion}

Overall, the level of implementation of the infusion of authentic elements in the teaching and learning process of Malay language essay writing was found to be moderately high. More specifically, teachers' understanding of authentic elements and the level of implementation of authentic elements in their teaching practice were moderately high. Ideally, a high level of such implementation is desirable, but that is not the case, as prevailing teaching conditions might have given them no 
choice, thus forcing them to rely on the traditional teaching method (Osman, 2013a and 2013b; Yusoff et al., 2010). More revealingly, correlational analysis performed showed that the relationship between school category and teachers' understanding was very weak and not significant. As such, this finding provides no evidence to not support the first research hypothesis. This finding suggests that the teachers of urban schools and non-urban schools have the same understanding of authentic elements in learning. Likewise, the relationship between school category and the level of implementation of authentic elements in teachers' teaching practice was very weak and not significant. As such, there is no evidence to not support the second research hypothesis. Such a finding indicates that the levels of implementation of such elements in the both categories of schools are similar.

The same correlational analysis showed that no significant relationship was established between teachers' experience and their understanding of the authentic elements in learning. As such, no evidence was found to not support the third research hypothesis. This particular finding suggests that the teachers' levels of understanding of such elements are the same for both experienced and less experienced teachers. Similarly, the analysis revealed that the relationship between teachers' experience and the level of the implementation of authentic elements in their teaching practice of Malay essay writing is not significant. Hence, there was no evidence to not support the third research hypothesis. With such a finding, it can be safely assumed that both experienced and less experienced teachers have been teaching with the use of authentic elements in equal numbers.

Again, the same correlational analysis was performed, indicating that the relationship between teachers' specialization and teachers' understanding of the authentic elements in learning was very weak and not significant. As such, this finding provides no evidence to not support the fifth research hypothesis, clearly indicating that teachers' levels understanding of authentic elements are the same irrespective of their specialization. Surprisingly, the same analysis showed that the relationship between teachers' specialization with the level of the implementation of authentic elements in their teaching practice of Malay essay writing was marginally significant, but weak. This unique finding provides some evidence to not support the sixth research hypothesis. From the statistical standpoint, it means that teachers who are more specialized have been using authentic elements in their teaching practice more often than their less specialized counterparts. From the practical standpoint, however, such a finding may not have a profound implication on the current practice, given that the strength of such a relationship is weak to have any substantial impact.

\section{Conclusion}

As observed, teachers' understanding and the implementation of authentic elements in their teaching practice is at the moderate level. As such, more efforts are entailed to raise the level of the use of authentic elements in the current teaching practice to higher level. In particular, the relations of their experience, specialization, and category of schools with the above factors were observed to be not significant. Even though the strength of the relationship between teachers' specialization and the implementation of authentic elements in their teaching practice was found to be small, such a finding may raise some concerns among the stakeholders, notably school administrators. Clearly, teachers who are less specialized in teaching Malay language writing may need more guidance to help them use more authentic elements in their teaching practice. As such, school administrators 
INTERNATIONAL JOURNAL OF ACADEMIC RESEARCH IN BUSINESS AND SOCIAL SCIENCES

Vol. 9, No. 1, Jan, 2019, E-ISSN: 2222-6990 @ 2019 HRMARS

need to allocate sufficient resources and support for such a group of teachers such that they can create an authentic learning environment in which their students can be taught more meaningfully.

\section{Acknowledgment}

This paper is based on a research project entitled Penerapan Elemen Autentik Dalam Pengajaran Penulisan Karangan Bahasa Melayu Tingkatan Dua Di Sekolah Berprestasi Rendah. The authors would like to extend their gratitude to the Research Management and Innovation Centre (RMIC), Sultan Idris Education University, Perak, Malaysia for the University Research Grant (Code 2017-0215107-01) that helped fund the research.

\section{Corresponding Author}

Zulkifli Osman, Malaysia, Email: zulkifli@fbk.upsi.edu.my

\section{References}

Shaari, A. S., Yusof, A. A., Khan, J. M. K., Mei, T. S., \& Teong, L. K. (2008). Keadilan Penilaian Prestasi dalam Kalangan Guru and Hubungannya dengan Motivasi Kerja and Prestasi Akademik Sekolah. International Journal of Management Studies (Bumper Issue). 15. hlm. 159-176.

Hashim, A. (2014). Panduan analisis data secara efisien. Dubook Press \& Publication, Cheras, Selangor

Daniels, E. (2007). Literacy café: making writing authentic. Voices from the Middle; Mar 2007; 14, 3; ProQuest Research Library. pg. 12

Esfahandiari, M. (2014). Task-Based Writing to Improve Young Teenage Learners' Reading Skills. World Journal of English language. 4 (1), 20-24.

Ghaderpanahi, L. (2012). Using Authentic Aural Materials to Develop Listening Comprehension in the EFL Classroom. English Language Teaching. 5 (6), 146-153.

Ghanbari, N. (2015). The Effect of Using Authentic Material on Iranian EFL Learners' Vocabulary Learning. Theory and Practice in Language Studies. 5 (12), 2459-2468.

Gilmore, A. (2007). Authentic Materials and Authenticity in Foreign Language Learning. Lang. Teach. Vol 40, 97-118.

Grim, F. (2010). Giving Authentic Apportunities to Second Langiage Learners. A Look at a Frech Service-Learning Project. Foreign language Annals. 43 (4), 605-623.

Guo, Shio-ching.(2012). Using Materials for Extensive Reading to Promote English Proficiency. English Language Teaching. 5(8), 196-206.

Husnin, H., Din, R., Karim, A., Norman, H., \& Hamdan, A. (2013). Assesing Authentic Learning via Storyboarding: A Malaysia Perspective. Asian Social Science. 9(16), 46-53.

Herrington, A. J. \& Herrington, J. A. (2007). What is an authentic learning environment?. In L. A. Tomei (Eds.), Online and Distance Learning: Concepts, Methodologies, Tools, and Applications (pp. 68-77). Hershey, PA: Information Science Reference.

Hussain Raja M. S. (2015). Relevance of Authentic Materials to the Attention Span of Edult Learners in English Learners Classes in Pakistan. Journal of Inquiry. 13 (2)., 53-73.

Klipfel, K. M. (2014). Authentic Engagment: Assessing the Effects of Authenticity on Student Engagement and Information Literacy in Academic Library Instruction. Reference Services Review. 42 (2), 229-245. 
INTERNATIONAL JOURNAL OF ACADEMIC RESEARCH IN BUSINESS AND SOCIAL SCIENCES

Vol. 9, No. 1, Jan, 2019, E-ISSN: 2222-6990 @ 2019 HRMARS

Mousavi, S. A. \& Iravani, H. (2012). The Effect of Authentic Versus Non-Authentic Aural Materials on EFL Learniers' Listening Comprehension. English Language and Literature Studies. 2 (1), 21 27.

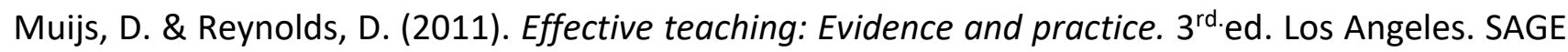
Publications Ltd.

Buyong, N. \& Othman, N. (2018). Pelaksanaan Pengajaran and Pembelajaran dalam Program Sekolah dalam Hospital. Jurnal Pendidikan Malaysia. 43(1), 11-16.

Yusoff, R., Wah, E. S. S, Jaafar, J., \& Ling, T. T. (2010). Kaedah Suapan dalam Kelas Bahasa Melayu: Satu Tinjauan Awal terhadap Pandangan Guru. Dalam Ambigapathy Pandian, Murshidi Harun @ Zakaria, Tan Hock Thye, Siti Noraini Jupri, and Noraini Ali (Eds.), Pancadimensi pengajaran and pembelajaran bahasa: Trend and amalan. Pulau Pinang: Penerbit Universiti Sains Malaysia (hlm. 207-216).

Zemelman, S., Daniels, H., \& Hyde, A. (2005). Best practices: Today's standards for teaching \& learning in America's School. $3^{\text {rd }}$ Edition. Portsmouth: Heinemann.

Zoghi, M., Zardak, F. M., \& Kazemi S. A. (2014). The Effect of Authentic Materials on Vocabulary Development. International Journal of Language Learning and Applied Linguistics World. 5 (4), 155-160.

Osman, Z. (2013a). Pembangunan Modul Pengajaran Bahasa Melayu secara Bersepadu. Tesis doktor falsafah yang tidak diterbitkan. Fakulti Pendidikan, Universiti Malaya.

Osman, Z. (2013b). Kebolehlaksanaan and Kebolehgunaa Modul Pengajaran Bahasa Berlandaskan Pendekatan Holistik. Jurnal Pendeta, Jilid 4, 202-230.

Osman, Z. (2016). Keberkesanan Pendekatan Autentik dalam Meningkatkan Tahap Penulisan Karangan Pelajar (The Effectiveness of Authentic Approach in Increasing Student Literacy Level). Jurnal Pendeta, Jilid 7, 142-155. 